\title{
Detection of potential diseases from wild rats (Maxomys bartelsii [Jentink, 1910]) using morphological evaluation of peripheral blood smears
}

\author{
Pangda Sopha Sushadi ${ }^{1}$ *, Syaiful Rizal ${ }^{1}$, and Endah Dwi J ayanti ${ }^{1}$ \\ 1Zoology Division, Research Center for B iology, Indonesian Institute of Sciences. Jalan Raya Jakarta-B ogor Km.46, Cibinong, \\ Indonesia 16911
}

\begin{abstract}
Recent studies show $60.3 \%$ of emerging infectious diseases are zoonoses and $71.8 \%$ of these number are obtained from wild animals in in-situ habitat. Therefore, high animal diversity in Indonesia is also followed by animal-borne diseases, both zoonoses or not. One of the in-situ habitats of wildlife that needs attention is the biosphere reserves. Here we conducted a research to analyze the health status of Maxomys bartelsii (J entink, 1910) rats from biosphere reserve in Gunung Gede Pangrango National Park. Rats were chosen because they are very potential for zoonoses transmission to human, such as leptospirosis, bubonic plague, and hantavirus. Peripheral blood samples were taken from 5 adult rats that were captured using live traps. Morphological evaluation of blood cells was carried out under a microscope at 1000x magnification. Our results show several erythrocyte abnormalities (hypochromasia, anisocytosis, and acanthocyte) and leukocyte abnormalities (neutrophilia, eosinophilia, and leukocytopenia) are observed in all individuals. These results indicate that most of rats suffered several pathological conditions that need to be explored.
\end{abstract}

\section{Introduction}

Indonesia has a very high diversity of animals, thus followed by the high threat of possibly-zoonotic animalborne diseases. Based on data from Jones et al. [1], as many as $60.3 \%$ of emerging infectious diseases (EID) were zoonotic and $71.8 \%$ of these came from wild animals in in-situ habitat. One of the in-situ habitats of wildlife that requires attention is the biosphere reserve. Aside from its appeal as a tourist destination, many socio-economic activities take place in the area. Interaction between visitors and wildlife is very possible, that make any anticipation of the potential transmission of disease to visitors is very necessary. Therefore, studies need to be conducted to determine the potential of diseases that can be transmitted by wildlife in a biosphere reserve.

Based on UNESCO [2], there are 14 biosphere reserves in Indonesia, including Cibodas Biosphere Reserve with Gunung Gede Pangrango National Park (TNGGP) as its core zone. Maxomys bartelsii rat (Jentink, 1910) is one of the many animals that live there. Like rats in general, these rat also have the potential to be a source of zoonotic diseases, such as leptospirosis, bubonic plague, and hantavirus [3]. These rats are endemic in the mountain forests of West Java and are not easily disturbed by the presence of humans around them, so that they can be found even in forest areas [4]. This makes $M$. bartelsii rat risky enough as a transmitter of disease to TNGGP visitors.

Observation on the health status of $M$. bartelsii in insitu habitat can be done by evaluating the morphology of its blood cells from peripheral blood smear [5]. According to Soepraptini et al. [6], as part of the body's circulatory system, blood consisting of erythrocytes, leukocytes, and platelet serves as a medium for transporting various substances the body needs and contains a lot of information about the physiology of an individual. This information is very useful to provide a picture of the potential diseases that can be transmitted by animals from an area. This study looked at the differentiation of leukocytes and erythrocyte cytology (size, shape, and color) of M. bartelsii sampled from TNGGP.

\section{Material and Methods}

As many as 30 mouse live traps were installed within a 1 $\mathrm{km}$ radius at TNGGP in the afternoon. Early the next morning, traps were examined and the rats that were caught immediately euthanized with intraperitoneal injection of $70 \%$ ethanol. There are five adult rats

\footnotetext{
Corresponding author: pang001@lipi.go.id
} 
collected. Blood samples were collected immediately as the rat died and blood smears were made on the slides seconds after. Three blood smear preparations are made for each individual. The blood smear samples are then aerated and then fixated in absolute methanol for 5 minutes. Next, $5 \%$ Giemsa staining is then applied to all samples. After that, the samples is rinsed with distilled water and observed under a microscope.

Calculation of RBCs and WBCs was referring to Durbin et al. [7] protocol to estimate erythrocytes and leukocytes counts in rats by blood smear examination with some modifications. A Euromex Iscope 1153 microscope was used to estimate cell counts. Cells were counted in 10 fields for each smear and the average number of cells per field was calculated. RBCs were counted using 1000x magnificat

\section{Result and Discussion}

Microscopic observations on the five blood smear samples showed several blood cell abnormalities as listed in Table 1. Variations in the size of erythrocytes (anisocytosis) appeared in two rats, mostly are macrocytes (Figure 1a). Erythrocytes of normal rat have an average diameter of 6-7 $\mu \mathrm{m}$ [8]. In macrocytic erythrocytes, the size of red blood cells increases from normal and the amount of hemoglobin per cell also increases [9]. Anisocytosis does not show a specific haematological abnormality, but can be caused by irregular response of erythrogenesis in the bone marrow due to anemia. In this case, the two rats that were experiencing anisocytosis also experienced hypochromasia, thus becoming an indication of anemia. In addition, anisocytosis often occurs when the rate of cell production is not the same, i.e. when the body's need for erythrocytes is very high or on $\mathrm{Fe}$ deficiency condition [10]. This condition is more common in old rats, from 22 months of age or more [8].

Blood cell values indicate abnormalities when compared to normal values in Sprague-Dawley mice (Table 2), but it should be noted that the normal values

Table 1. Blood cell abnormalities of each individual

\begin{tabular}{|c|c|c|c|c|c|c|}
\hline $\begin{array}{c}\text { Rat } \\
\text { sample } \\
\text { no. }\end{array}$ & Anisocytosis & Hypochromasia & Acanthocyte & Neutrophilia & Eosinophilia & Leukocytopenia \\
\hline $1(ठ)$ & + & + & & & & \\
\hline $2\left(\partial^{\lambda}\right)$ & + & + & & & & \\
\hline $3(9)$ & & + & & + & + & \\
\hline 4 (早) & & + & & & & + \\
\hline $5\left(\partial^{\lambda}\right)$ & & & + & & & \\
\hline $5(\widehat{O})$ & & & + & & & \\
\hline
\end{tabular}

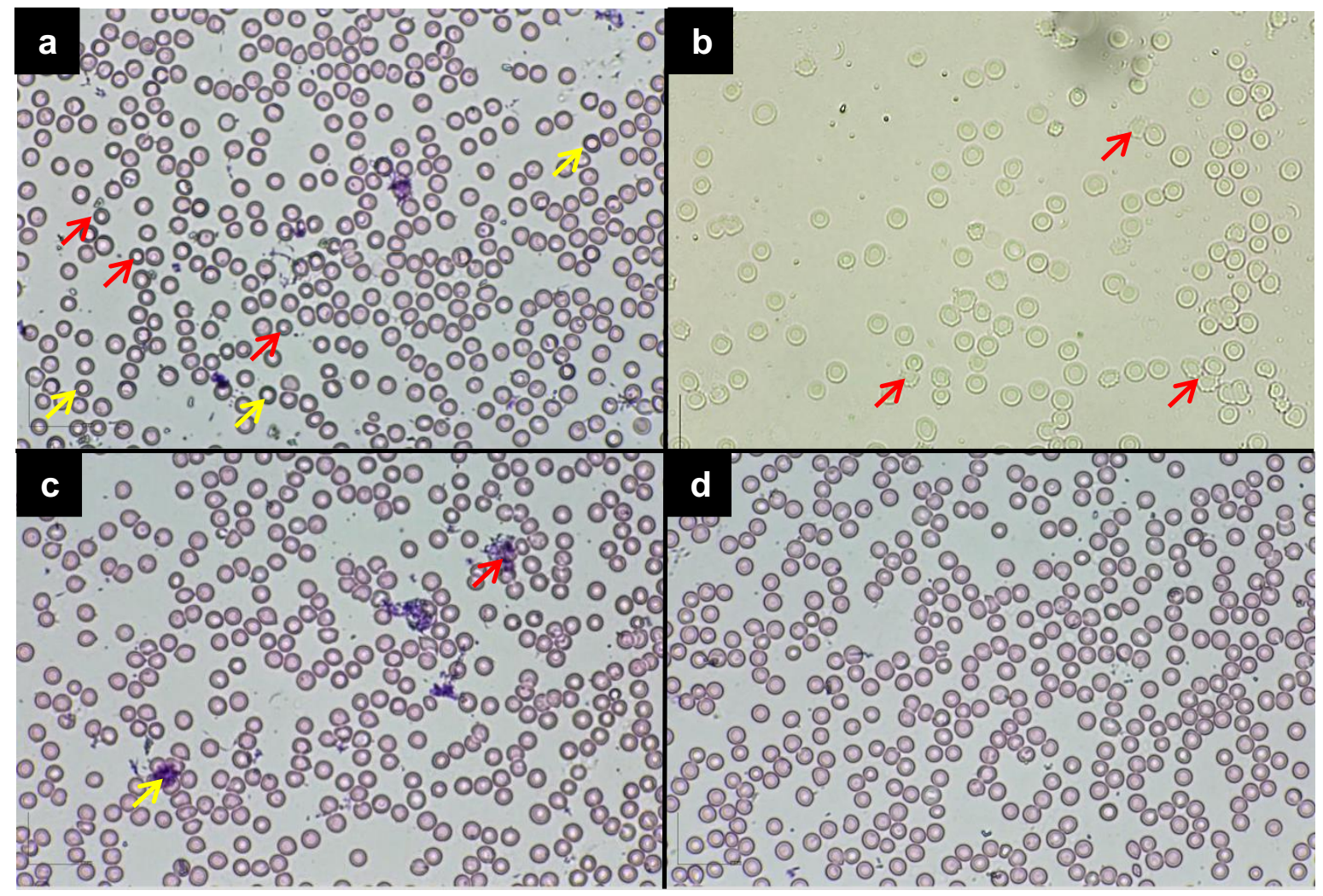

Fig. 1. Peripheral blood smears of M.bartelsii with several abnormalities: a. hypochromasia (yellow arrows) and anisocytosis (red arrows); b. acanthocytes (red arrows); c. neutrophilia (red arrows) and eosinophilia (yellow arrows), and; d. leukocytopenia 
between these species may have differences, so further study is needed to determine whether the results here are truly abnormal or only normal variations among each species. The results shown in both rats, leukocyte abnormalities occurred. An increase in the number of leukocytes is a common feature of infection in the body. Types of infections can be determined based on the type of leukocytes increased [15]. In one of the rats, neutrophilia and eosinophilia occurs (Figure 1c), while the other had leukocytopenia (Figure 1d). The increase in eosinophils indicates a parasitic/helminth infection [16], whereas an increase in neutrophils can be caused by bacterial infections [7], but in this case it is likely caused by a response to stress due to trapping [17]. Parasitic/helminth infections are very likely to occur and are thought to be the cause of hypochromic anemia which is also observed as erythrocyte hypochromasia. The existence of blood-sucking worms in the digestive tract of these rat needs to be confirmed again with further examination.

Table 2. Blood cell values for each individual

\begin{tabular}{|c|c|c|c|c|c|c|c|}
\hline $\begin{array}{c}\text { Rat } \\
\text { sample } \\
\text { no. }\end{array}$ & $\begin{array}{c}\mathrm{RBC} \\
\left(\times 10^{6} / \mathbf{m m}^{3}\right)\end{array}$ & $\begin{array}{c}\text { WBC } \\
\left(\times 10^{3} / \mathbf{m m}^{3}\right)\end{array}$ & $\begin{array}{c}\text { Neutrophils } \\
(\%)\end{array}$ & $\begin{array}{c}\text { Lymphocytes } \\
(\%)\end{array}$ & $\begin{array}{c}\text { Eosinophils } \\
(\%)\end{array}$ & $\begin{array}{c}\text { Monocytes } \\
(\%)\end{array}$ & $\begin{array}{c}\text { Basophils } \\
(\%)\end{array}$ \\
\hline $1\left(\delta^{\lambda}\right)$ & 6.34 & 20.5 & 22.7 & 89.0 & 0.0 & 2.5 & 0.0 \\
\hline $2(3)$ & 5.92 & 18.4 & 21.5 & 73.5 & 0.0 & 2.6 & 0.0 \\
\hline $3(+)$ & 7.73 & 15.8 & 30.3 & 95.0 & 2.6 & 2.0 & 0.0 \\
\hline $4($ (P) & 4.61 & 3.2 & 1.5 & 41.0 & 0.0 & 0.0 & 0.0 \\
\hline $5\left({ }^{\Uparrow}\right)$ & 6.31 & 20.2 & 21.9 & 96.0 & 0.2 & 1.8 & 0.0 \\
\hline
\end{tabular}

In rat with leukocytopenia, folate, $\mathrm{Zn}, \mathrm{Fe}$, or $\mathrm{Cu}$ deficiency may occur, which results in suboptimal production of blood cells. Another possibility is the abnormality in the bone marrow as a producer of blood cells [18]. Viral infections that attack the immune system can also cause this condition, but cannot be confirmed without further examination [19]. One other rat was observed to experience an abnormality of acanthocytes. Acanthocytes is an abnormalities of erythrocytes shape that are irregular and the edges usually appear to be spiculated. Acanthocytes mostly occur in many cases of cirrhosis and pancreatitis [20]. Some other diseases that have been recorded can cause acanthocytes including congenital abetalipoproteinemia, hypothyroidism, deficiency of vitamin E, chronic liver disease, and hemolytic anemia due to autoimmune reactions [21]. However, acanthocytes can also be observed in blood samples that are not immediately processed or stored at $3^{\circ} \mathrm{C}[22]$.

To sum it up, of the five sampled rats, all had blood cell abnormalities based on peripheral blood smear examination. Further investigation to confirm the alleged infection or cause of the disease that has been stated earlier, may lead to the findings of several zoonotic agents, although the data obtained and the number of samples collected are still less than ideal. The most important thing is the awareness for the management that there is always a risk for disease transmission from animals in biosphere reserves, so that preventive measures could be taken, either by educating the visitors or proactively conducting periodic disease surveys.

\section{Conclusion}

There might be any pathogenic infection in wild rats on Gunung Gede Pangrango National Park. However, further comprehensive investigation and bigger sample size is needed.

\section{References}

1. K.E. Jones, N.G. Patel, M.A. Levy, A. Storeygard, D. Balk, J.L. Gittleman, P. Daszak, Nature 451, 7181 (2008) doi: 10.1038/nature06536

2. UNESCO, Biosphere Reserves in Indonesia (2015) http://www.unesco.org/new/en/naturalsciences/environment/ecological-sciences/ biosphere-reserves/asia-and-the-pacific/indonesia/

3. K. Boey, K. Shiokawa, S. Rajeev, PLoS Negl Trop Dis 13, 8 (2019) 10.1371/journal.pntd. 0007499

4. K. Aplin, Maxomys bartelsii (The IUCN Red List of Threatened Species 2016: e.T12893A22456458. http://dx.doi.org/10.2305/IUCN.UK.2016-

2.RLTS.T12893A22456458.en. Downloaded on 13 May 2019)

5. J.A. Shagana, J Pharm Sci Res 6, 4 (2014)

6. J. Soepraptini, K. Widyayanti, A.T.S. Estoepangestie, JIKH 4, 1 (2011)

7. C. Durbin, K. Guo, W. Hoffman, A.E. Schultze, S. White, Vet Clin Pathol 38, 2 (2009) DOI: 10.1111/j.1939-165x.2009.00110.x

8. Y. Bailly, P. Duprat, Monographs on Pathology of Laboratory Animals, 27-38 (1990) DOI: 10.1007/978-3-642-84110-1_3

9. T.R. Gregory, Genome, 43 (2000)

10. J.A. Eurell, B.R. Frappier, Dellmann's Textbook of Veterinary Histology. $6^{\text {th }}$ (Ed. John Wiley \& Sons, USA, 2013)

11. M.L. Turgeon, Clinical Hematology: Theory and Procedures. $5^{\text {th }}$ Ed. (Lippincott Williams \& Wilkins, USA, 2012)

12. M. Seguel, N. Gottdenker, IJPPAW 6, 3 (2017) doi: 10.1016/j.ijppaw.2017.03.007 
13. E. Purwaningsih, Biota 8, 3 (2003) DOI: 10.24002/biota.v8i3.2851

14. K. Chaisiri, P. Siribat, A. Ribas, S. Morand, Vector Borne Zoonotic Dis. 15, 1 (2015) DOI: 10.1089/vbz.2014.1619

15. W.J. Bacha Jr, L.M. Bacha, Color Atlas of Veterinary Histology. $2^{\text {nd }}$ Ed. (Lippincott Williams \& Wilkins, USA, 2000)

16. D.G. Rudmann, T.J. Page, J.L. Vahle, L. Chouinard, S. Haile, F. Poitout, G. Baskin, A.J. Lambert, P. Walker, G. Glazier, M. Awori, L. Bernier, Toxic Sci. 125, 2 (2011) DOI: 10.1093/toxsci/kfr318
17. W.L. Lee, R.E. Harrison, S. Grinstein, J Microb Infect, 5 (2003)

18. M.C.L. Pinto, M.M. Melo, M.E.R. Costa, C.R. Labarrere, Arq Brasil Med Vet Zoo. 62, 2 (2010) doi: 10.1590/s0102-09352010000200015

19. M.M. Khatun, M.A. Islam, B.K. Baek, Int J Hematol Res 2, 3 (2016)

20. A.L. Zilber, P. Belli, M. Artois, A. Kodjo, Z. Djelouadji, Bio Med Res Int, 2016 (2016). DOI: 10.1155/2016/9656274

21. R. Cowell, Veterinary Clinical Pathology Secrets (Elsevier, UK, 2004)

22. M.C. Cora, D. King, L.J. Betz, R. Wilson, G.S. Travlos, JAALAS 51, 5 (2012) 